may be caused partially by degradation products of DNA. A more detailed analysis of the acid-soluble fraction is now in progress.

These results are examples from a series of experiments under various ccnditions. Longer incubation of $E$. coli $B$ cells with MC caused degradation of RNA and protein too. No degradation occurred when deoxyribonucleic acid from calf thymus and nucleic acid from herring sperm were incubated with MC in vitro under the same conditions as described here.

Takagi and Sekiguchi postulated that the in. hibition of DNA formation in growing cells of $E$. coli $B$ treated with $\mathrm{MC}$ is caused by an attack on synthesizing steps during DNA formation. However, they could not find any influence of MC on the polymerizing Kornberg enzyme. Furthermore, tha block in DNA synthesis induced by $\mathbf{M C}$ was not overcome by the addition of thymine, thymidine or a mixture of deoxyribonucleotides to the medium.

The question arises: Is the inhibition of DNA formation in $E$. coli $B$ treated with MC really caused by an attack in the synthesizing steps during DNA formation? The results presented here show that MC, under the experimental conditions described above, acts on the depolymerization of DNA*. If, in the presence of low levels of $\mathrm{MC}$ in the incubation medium of growing $E$. coli $B$ cells, the synthesized DNA is partially degraded, the resulting picture is a block in DNA formation.

* Note added in proof. Tatum and co-workers obtained similar results (see ref. 7).

$$
\text { H. Kersten }
$$

H. M. RAUEN

Physiologisch-Chemischen Institut,

Universität Münster, Westfalen.

1 Shiba, S., Terawaki, A., Taguchi, T., and Kawamata, J., Nature, 183, 1056 (1959).

${ }^{2}$ Sekiguchi, M., and Takagi, Y., Biochim. Biophys. Acta, 41, 434 (1960).

3 Kersten, W. Kersten H, and Rauen, H. M. Nature, 187, 60 (1960).

Rauen, H. M., Kersten, H., and Kersten, W., Z. physiol. Chem., 321 $139(1960)$.

5 Kersten, W., Biochim. Biophys, Acta, 47, 612 (1961).

- Otsuji, N., Sekiguchi, M., Iijima, T., and Takagi, Y., Nature, 184 1079 (1959).

'Reich, E., Shatkin, A. J., and Tatum, E. L., Biochim. Biophys. Acta, 45, 608 (1960).

\section{Ethanol Stimulation of Oxidative Metabolism in Euglena gracilis}

Euglena gracilis, a flagellate protozoan, utilizes acetate and ethanol as energy and carbon sources. The acetate metabolism of Euglena grown on ethanol differs from that grown on acetate. Ethanol-grown cells have a rate of acetate oxidation at $p \mathrm{H} 7.0$ lower than that of acetate-grown cells ${ }^{1}$. However, ethanolgrown cells incubated in the presence of acetate for about $80 \mathrm{~min}$. often adapt to acetate, taking on characteristics similar to those of acetate-grown cells ${ }^{1,2}$. Thus, it was considered of interest to determine the respiration of Euglena in the presence of both acetate and ethanol.

Experimental and stock cultures of a streptomycinbleached strain, $S M-L I$, of Euglena gracilis var. bacillaris, were grown axenically on the defined Cramer-Myers medium ${ }^{3}$ with $0.061 M$ acetate as the sole carbon source for growth. The cells were gathered during the logarithmic growth phase, centrifuged twice in basal Cramer-Myers medium (minus acetate and vitamins $B_{1}$ and $B_{12}$ ), and re-suspended in a small volume of the basal medium. Cell concentrations ranged from $1.0 \times 10^{6}$ to $3.7 \times$
Table 1. Ethanol and ACetate Respiration * OF Intact, Acetate-

Average $\mathrm{QO}_{2}$ for the acetate control (no ethanol) was $22 \cdot 8 \mu \mathrm{l} . \mathrm{O}_{2} / 10^{6}$ cells/hr. Acetate concentration $(0.061 M)$ was constant in all experiments. The control for each experiment was standardized $\begin{array}{r}\text { at } 100 \text { per cent } \\ \hline\end{array}$

\begin{tabular}{|c|c|c|}
\hline Ethanol molarity & $\begin{array}{c}\text { No. of } \\
\text { experiments }\end{array}$ & $\begin{array}{c}\text { Average percentage } \\
\text { of control }\end{array}$ \\
\hline 0 & 5 & $100 \cdot 0$ \\
$6.83 \times 10^{-2}$ & 4 & $108 \cdot 0$ \\
$3.41 \times 10^{-2}$ & 3 & $112 \cdot 0$ \\
$1.71 \times 10^{-2}$ & 3 & $122 \cdot 0$ \\
$3.41 \times 10^{-3}$ & 5 & $113 \cdot 0$ \\
$6.83 \times 10^{-4}$ & 4 & $102 \cdot 0$ \\
$3.41 \times 10^{-4}$ & 4 & $97 \cdot 0$ \\
$1 \cdot 71 \times 10^{-4}$ & 3 & 97.5 \\
$3.41 \times 10^{-5}$ & 3 & \\
\hline
\end{tabular}

$10^{6}$ cells per flask. Absolute ethanol, in the amounts shown in Table 1, was added to Cramer-Myers medium which was then pipetted in $1 . \mathrm{ml}$. quantities into the side-arms of the respiration flasks. The acetate concentration $(0.061 M)$ was held constant in all experiments. Respiration-rates were determined by the direct method of Warburg. After the substrate was tipped in, readings were taken at $10-\mathrm{min}$. intervals for $60 \mathrm{~min}$. Respiration-rates were measured as $\mu \mathrm{l} . \mathrm{O}_{2} / 10^{6}$ cells $/ \mathrm{hr}$. and are reported as per cent of the acetate control. All other conditions were as reported previously ${ }^{5}$.

It is evident from Table 1 that the respiration of Euglena in the presence of acetate is stimulated by ethanol, a finding not reported before in the literature. The maximum effect of ethanol in these experiments occurs at a concentration of $3.41 \times 10^{-3} M$. Higher and lower concentrations of ethanol result in a decreasing effect on the respiration of Euglena.

It appears that the ethanol may be affecting the cells by being oxidized within the cells to acetate, which in turn could enter the citric acid cycle or, perhaps, stimulate the formation of lipids. Bearing on this problem is a recent observation ${ }^{6}$ which indicates that, in Euglena grown in the presence of both acetate and ethanol, more acetate carbon is assimilated into protoplasm than is oxidized as compared with cells grown in the presence of acetate alone. Although it has not been determined what substances are being formed in Euglena cells under these conditions, further work with labelled acetate and/or ethanol should help to explain these observations.

\section{E. Buetow}

Gerontology Branch, National Heart Institute, Baltimore City Hospital, Baltimore 24, Maryland.

${ }^{1}$ Danforth, W. F., and Wilson, B. W., J. Protozool., 4, 52 (1957).

"Wilson, B. W., and Danforth, W. F., J. Gen. Microbiol., 18, 535 (1958).

${ }^{3}$ Cramer, M., and Myers, J., Arch. Mikrobiol., 17, 384 (1952).

4 Umbreit, W.. Burris, R., and Stauffer, J., Manometric Technique (Burgess Pub. Co., Minneapolis, 1957).

'Wilson, B. W. Buetow, D. E., Jahn, T. L., and Levedahl, B, H. Exp. Cell. Res., 18, 454 (1959).

- Danforth, W. F., J. Protozool., 7 (Supp.), 14 (1960).

\section{A Factor associated with 'Visking' Tubing capable of Antagonizing Insulin}

DURING the investigation of the insulin antagonism associated with human serum albumin', 'Visking' tubing (Visking Corporation, Chicago, U.S.A.) was used for ultrafiltration and dialysis of protein solutions. The tubing itself has since been found to give rise to a substance which antagonizes insulin and which appears in the following circumstances: 